\title{
Energy investments in renewable energy sources as a way towards enterprises' sustainable development
}

\author{
Greta Poszwa ${ }^{1 *}$ \\ ${ }^{1}$ Stanisław Staszic State University of Applied Sciences in Pila, 64920 Pila, Poland
}

\begin{abstract}
Sustainable development is a pervasive philosophy that every participant in the global economy (including consumers and government) must agree with if today's needs are to be met without risking the ability of future generations to meet their own. According to this premise, the idea of sustainable development cannot be implemented by a single enterprise (or even the entire business community) in isolation. In their activities, business entities wanting to apply the philosophy of the balanced use of all resources necessary in the production process should take into account the assumptions included in the seventeen priority goals of sustainable development in the decision-making process. This article shows how enterprises can both achieve business goals and focus on environmental protection through the implementation of energy investments. However, it also shows that the mere awareness of the need to implement energy investments in their organizations is not sufficient to achieve these goals, and the level of investments in this respect among small and medium-sized enterprises is moderate.
\end{abstract}

Keywords: energy investments, renewable energy sources, enterprises, sustainable development

\section{Introduction}

The impact of human activity on changes taking place in the natural environment is repeatedly discussed in many magazines. The relationship between man and the environment is the subject of interest for many social groups that feel responsible for the state and quality of the surrounding nature. The development of civilization, the constantly changing and growing needs of the human beings resulted in a dynamic increase in production. The development of enterprises, and their desire to maximize profits obliterated the need to take care of the natural environment. Until the 1950 s, the natural environment was considered a common good. The system which did not require payment for using natural environment resources caused an increase in pollution, water degradation, and the production of large amounts of non-biodegradable waste [1].

\footnotetext{
* Corresponding author: gposzwa@gmail.com
} 
The disturbing state of the environment was a trigger for developing methods of implementing the concept of technology, the theory and theorems of which were incorporated into the concept of environmental development, as a method of preparatory proceedings for the purposes of environmental and economic development. Environmental goals, in accordance with the concern for the natural environment, should constitute an indispensable element of the decision-making process in the dimension of economic and social life [2](pp. 33-40).

Entrepreneurs who want to run their businesses in accordance with the sustainable development concept must implement the applicable rules and principles in all areas of the company's operations. In this respect, energy investments are particularly important, as they are reflected in the economic calculation of the enterprise (reduction of energy consumption and the associated reduction of energy costs) as well as having a positive impact on environmental protection by reducing $\mathrm{CO} 2$ emissions into the atmosphere. The reduction of the amount of $\mathrm{CO} 2$ takes place, for example, through the improvement of energy efficiency obtained as a result of the implementation of energy investments. Converting fossil fuels into energy from renewable resources is an important step towards achieving the guidelines that represent the essence of the sustainable development concept. It is investments in renewable energy sources that allow for the implementation of these assumptions. The purpose of this article is to analyse energy investment projects implemented by small and medium-sized enterprises, with the particular emphasis on investments in the field of renewable energy sources. The low level of investment is one of the key problems of the Polish economy. Meanwhile, knowledge and its skilful use have recently become the basic factors determining the attractiveness and competitiveness of the economy on the global market. Taking into account the above-mentioned factors, the article adopts the hypothesis about a moderate level of investment activities in the field of renewable energy sources by small and medium-sized enterprises in the Greater Poland Voivodeship.

\subsection{Sustainable development: definition, principles, assumptions}

Recognition of ecological awareness in production processes is the result of observing and appreciating the importance of the relationship between human economic activity and the process of the nature's destruction and degradation. A query of literature gives several definitions of ecological awareness. One of them is in line with the pragmatic and systemic idea of nature protection that was initiated in the late 1960s. The pragmatic idea is aimed at nature protection in terms of caring for and protecting the natural environment. It consists in the liquidation of industrial plants which are a great threat to the environment through the production of plentiful pollution, sewage and waste that pose a threat to human health and life. It assumes that the implementation of projects constructing new enterprises of this type should be abandoned; the implementation of pro-ecological investments should be promoted and supported; there should be created legal and economic instruments for regulating the amount of anthropogenic pressure on the environment. It promotes the idea of developing and implementing clean production technologies, reducing material and energy inputs per production unit $[1]$ (p. 12).

Sustainable development is a ubiquitous philosophy that every participant in the global economy (including consumers and government) must agree with if today's needs are to be met without compromising the ability of future generations to meet their own. According to this premise, the idea of sustainable development cannot be implemented by a single enterprise (or even by the entire business community) in isolation.

The world is struggling with major problems related to the poor state of the environment, its degradation and the excessive use of its resources. One of the reasons for this state of affairs is permanent economic growth, development of enterprises and changes in behaviour 
and consumption patterns [3]. The reaction to this is increasingly restrictive environmental regulations that limit or even inhibit economic growth [3]. As a consequence, business opportunities and the use of the economic potential of enterprises are held back. The result can be a harmony between an undamaged and healthy environment and controlled and responsible economic development. Compromises are forms of development that are both environmentally and socially sustainable. They lead to improving environmental values, allow the implementation of investment projects - pro-development, not burdening environmental capital. Businesses and societies need to find approaches that work simultaneously towards all three goals: environmental protection, social welfare and economic development.

The concept of sustainable development is gaining more and more recognition, and for many managers and business owners it is a new way of running a business. However, for most of them, this concept still remains in the realm of abstraction and theoretical principles [4]. The protection and development of the company's capital base is the main and traditional business principle. Organizations do not yet see the need to extend this activity to the area of protecting natural and human resources. The idea of sustainable development presents the concept of enterprises adopting such strategies and business activities that achieve the goals of the enterprise and its stakeholders. At the same time, business activities must be directed towards the protection, maintenance and enhancement of human and natural resources that will be necessary in the future [5]. This is the definition originally formulated by the World Commission on Environment and Development, which indicates that development must meet the needs of the company and its partners, which include, in addition to shareholders, also lenders, customers, employees, suppliers, and communities whose activities are highly influenced by the organization. Defined in this way, sustainable development emphasizes the dependence of business not only on physical and financial capital, but also on human and natural resources. This definition also highlights the fact that economic activity cannot irreversibly degrade or destroy natural and human resources [5].

\subsection{Sustainable development and company management}

Enterprises wishing to comply with these principles must incorporate these guidelines into the implementation of their policies, strategies and processes. Scientists and researchers do not point to the need to create new management methods in this area. This requires creating a new cultural orientation and the wide-ranging refinements of systems, practices and procedures already present in the enterprise. These improvements and changes are primarily the inclusion of the principles and the idea of sustainable development in all areas of the company's operations so far and treating them on an equal footing with the existing principles of decision making, strategy building and company goals. However, in the implementation of the sustainable development concept implemented in the company, there are two new areas that have not been present so far, i.e., increasing responsibility towards all stakeholders and creating new reporting rules.

The new reporting rules are associated with establishing an effective framework for sustainable development management, which is to cover both the decision-making process and the management process of the entire enterprise and its individual units. The concept of sustainable development is a process integrated with both business planning, and the management information and controlling systems. Decisions made at all levels should be directed at greater sensitivity of problems resulting from the premises of the idea of sustainable development. Managing a company in accordance with the principles of sustainable development requires seven steps:

1) analysing all stakeholders,

2) setting policies and goals for sustainable development, 
3) creating a plan of implementing the principles of sustainable development to the enterprise,

4) creating a new corporate culture supporting the idea of sustainable development,

5) designing new measures and performance standards,

6) preparing reports in accordance with the new management principles taking into account the principles of sustainable development,

7) improving internal monitoring processes [6].

Managers in the process of making decisions and building strategies should make conscious choices that are based on the rational use of raw materials, energy savings, which is a reference to the conscious use of the environment with simultaneous care for its condition. The standard should also prefer low-waste and non-waste technologies (the socalled clean technologies). Production and service activities carried out by enterprises should base their course on the principles proclaimed by, for example, the concept of Clean Production (CP) [6].

The idea of sustainable development implemented in an enterprise also entails the need to carry out investment projects in line with its principles. Managers of companies responsible for this area of the company's operations, in the process of making investment decisions, are guided by the choice of technological solutions that belong to the investment group, technologies such as BAT - Best Available Technology, PPP- Pollution Producer Pays, and the related rules of prevention and substitution.

Enterprises wishing to achieve environmental goals must make decisions related to implementing pro-ecological investments. In many cases, environmental management tools require the company to commit a certain number of financial outlays. Pro-ecological investments require the involvement of additional financial resources and technological resources, which often leads to the reduction or even abandonment of other projects related to the company's operations. The need to allocate funds from development investments or adaptation projects to pro-ecological investments is an additional financial burden for the enterprise, which affects the production efficiency and deteriorates the company's financial indicators, i.e., liquidity ratio, debt ratio, etc [3].

\subsection{Energy policy: assumptions and new trends}

Reducing the consumption of energy from traditional sources and switching the countries' entire economies to obtain the energy from renewable sources is one of the key goals for environmental protection [7, 8]. Every year, the world emits about 30 billion tons of carbon dioxide (CO2), which comes from burning wood, coal, gas, oil as well as burning forests, stubble, meadows etc. The concentration of $\mathrm{CO} 2$ has increased from 315 to 385 p.p.m. (parts per million) over 250 years and has been still increasing [9]. It is heavily emphasized that the ecological effect of using renewable energy sources is zero $\mathrm{CO} 2$ emission resulting from the use of solid, liquid and gaseous biofuels $[10,11]$. The change in the direction of meeting the economies' energy needs from renewable energy instead of conventional sources is dictated by the treatment of renewable energy, in the context of energy law, as the possibility of implementing three main postulates related to environmental safety (environmental and climate protection), energy security, and strengthening the competition of enterprises and the position of individual consumers [7, 8]. Reorientation of the demand for energy from conventional sources to renewable sources also means the implementation of the constitutional principle of sustainable development. The concept of sustainable development essentially requires looking for such paths of energy development that lead to a balanced use of traditional and renewable energy sources [12]. The need to maintain balance does not change the well-known and proven statement that renewable energy sources contribute more 
to maintaining good condition and environmental protection than fossil sources, which should be the overriding goal not only for the present, but also for future generations [13].

Saving energy, avoiding the emission of significant amounts of $\mathrm{CO} 2$ and reducing electricity costs for end users are the basic benefits of increasing the energy efficiency of production and operation processes. Pursuant to the EU Directive 2006/32 / EC of 5 April 2006 on the energy end-use efficiency and energy services, the priority objective is to achieve the national indicative energy savings target of $9 \%$ within 9 years from the directive coming into effect [14]. For Poland this means the necessity to introduce primary energy savings by 2016. This should be achieved through energy services and alternative methods of improving energy efficiency. A secondary objective of the directive is to reduce $\mathrm{CO} 2$ emissions as a result of the reduction of fossil fuel consumption in the EU [14]. For several years, Poland has made attempts to create a new model of energy strategy, the design of which should, on the one hand, take into account the needs of consumers, and on the other hand, take into account the challenges posed by the European Union [15]. The most important operational goals of the strategy are: to ensure the country's energy security, to reduce the environmental impact of the energy sector, to increase the energy efficiency and competitiveness of the national economy [16].

The Polish energy sector will face new challenges in the coming times: power market, electromobility, expansion of the transmission network, investments in generation capacity, development of distributed energy, and, most of all, finding the optimal model for the operation of renewable energy sources. Taking into account the requirements of the climate policy, the government's actions must strive for a greater balance in the fuel mix so that the development of the energy sector can be continued on the basis of sustainable development for the next 10 years [15].

Poland is obliged to implement the assumptions of the EU energy policy in terms of achieving a $15 \%$ share of renewable energy sources (RES) in final energy consumption by 2020 , which means the need to invest in new generation capacities using the so-called clean energy sources [17].

\subsection{Energy efficiency as a path to sustainable development}

Implementation of the national plan to improve the energy efficiency requires launching all methods that provide this possibility. Using the full potential means mobilizing the resources in three areas:

- the energy generation sector,

- energy transmission and distribution,

- energy end-use.

The possibility of introducing improvements in energy efficiency in the area of energy end-use depends on the awareness of the problem importance on the part of the behavioural models of households, public sector entities and enterprises [18].

Institutions researching the basis of behaviour and decision-making by small- and medium-sized enterprises (SMEs) in the field of energy efficiency improvement show that most companies from the SMEs sector define the problem of using electricity and improving energy efficiency as important. Failure to take specific actions related to it concerns the deficit of people who can be entrusted with its implementation - staff deficit, problems with qualifications, lack of professional knowledge [19]. The Polish Chamber of Commerce's research on incentives and barriers to improving energy efficiency in SMEs showed that only $7 \%$ of the companies surveyed carried out an energy audit. $78 \%$ of the respondents did not consider introducing an energy management system. It is not common to use investment financing by an energy service company in return for a share in the investments made (ESCO - Energy Service Companies). Most of the SME owners spend their own resources on the 
implementation of pro-efficiency investments. Research shows that the implementation of these investments brings certain financial benefits to enterprises, however, only $1 / 5$ of the respondents measure the results achieved. The research results clearly show that the main barriers to improving the energy efficiency of SMEs result from the lack of knowledge, information and financial support [20].

\subsection{Entrepreneurs and their behaviour patterns in the investment projects}

In the process of making investment decisions, entrepreneurs are mostly guided by financial benefits. In many companies, an important cost in the current budget is the cost of energy. Entrepreneurs who invested their resources in profitable projects are willing to optimize their costs. Conducting projects, including those from operational groups, i.e., changing the energy supplier to a cheaper, more flexible one or changing the tariff to the one better suited to the company's needs, ending with development investments, more complex both technologically and organizationally, i.e. investments in transformers, reactive power compensators or, after all, in RES improves the company's energy efficiency and brings tangible financial benefits to its owners [21].

The main benefit and motivator of investments in renewable energy sources in the SME sector is the reduction of energy costs and the associated savings. In the situation of drastically rising electricity prices in Poland, having one's own source of generation is the only protection (in a certain amount) against the effects of price increases. Thanks to lower energy costs, especially in energy-intensive groups, it is also an element of increasing the price competitiveness of manufactured products or services. Another group of benefits from the implementation of investments in renewable energy for SMEs is an access to additional power generated by power plants from renewable energy sources. In some cases, it is the main possibility that guarantees business development in the areas where network power resources are insufficient to meet the growing needs of energy consumers. A large number of entrepreneurs treat the implementation of these projects as a form of pursuing the company's sustainable development policy, care for ecology, and building a positive image of a company that respects the environment [21].

The introduction of regulations for renewable energy sources in 2015 resulted in an increase in the number and capacity of renewable energy micro-installations in the entire power system. A large part of them is implemented as pro-consumer installations for individuals and farmers. There is a growing interest in this type of ventures among entrepreneurs. The dominant technology in both micro-installations and small installations is photovoltaics.

\subsection{Sources of financing investment barriers of enterprises in implementing energy investments}

In the 2014-2020 EU perspective, the national program addressed to a group of small and medium-sized enterprises in the field of improving energy efficiency is "Energy-saving investments in small and medium-sized enterprises [22]. The program aims to reduce energy consumption as a result of investments in energy efficiency and the use of renewable energy sources. The final result is the reduction of $\mathrm{CO} 2$ emissions. The institution implementing the program is the National Fund for Environmental Protection and Water Management. Investments eligible for financial support from the program include:

a) purchase of equipment mentioned in the List of Eligible Materials and Equipment (LEME) - projects financed from this activity cannot exceed a loan with a subsidy of EUR 250,000, which is the equivalent of Polish zlotys according to the average exchange rate of the National Bank of Poland on the date of signing the loan agreement; 
b) investment projects to improve energy efficiency, based on individual solutions with the need to achieve min. $20 \%$ energy savings. The value of financing in the form of a loan with a subsidy may not exceed EUR 1,000,000;

c) thermal modernization of the building(s) at the disposal of the beneficiary, as a result of which a minimum of $30 \%$ energy savings will be achieved. Financing in the form of a loan with a grant for these projects cannot exceed EUR 1,000,000;

d) investments involving the use of renewable energy sources, including i.a. photovoltaics, in existing facilities using conventional energy sources. Financing from external sources (credit with a grant may not exceed EUR 1,000,000 [23, 24].

The European Bank for Reconstruction and Development finances and implements the PolSEFF program - the Sustainable Energy Financing Program in Poland, with a budget of EUR 150 million [25]. The offer of PolSEFF is addressed to small and medium-sized enterprises in Poland. Financing can be obtained in the form of a loan or leasing. The amount of loans that entrepreneurs can apply for from this program is also up to EUR 1 million. The subject scope of the program covers:

a) investment projects assuming the final result in the form of savings in energy consumption by at least $20 \%$,

b) investments covering selected technologies - investments in projects and equipment selected from the prepared list of technologies,

c) investment projects improving the efficiency of energy use in buildings, which enable the reduction of energy consumption in commercial and administrative buildings of SMEs by $30 \%$,

(d) investments in renewable energy sources.

Financing from the Regional Fund for Environmental Protection and Water Management or other subsidy programs is a very time-consuming and often complicated process. Entrepreneurs are obliged to prepare application documentation, achieve and maintain the environmental effect and settle the project. The form of closed competitions additionally slows down the process of financial support. The procedures take from one to two years, which very often discourages the participation of more entrepreneurs. Besides, limited funds mean that a small number of applications can be financed [21](p. 78).

Leasing is a much friendlier way of financing investments in renewable energy sources for entrepreneurs. In Poland, several banks currently provide leases for the purchase of renewable energy installations, including PKO Leasing, and De Lage Landen Leasing Polska. For commercial institutions, however, this group of investments is highly risky. The risk is related to the RES product itself, because for the bank it is a product that cannot be sold again due to the lack of a secondary market for RES installations. As a result, the financing institution, in the event that the lessee ceases to pay off the leased object, is not able to recover the money by reselling the object leased [26].

Despite the existing financial tools supporting the investments in question, the research carried out by the European Leasing Fund mentions many barriers indicated by SME owners, including:

a) high initial installation costs,

b) long payback period,

c) low amount or no funding at all [27].

Among the entrepreneurs surveyed, owners of micro-enterprises, much more often than other respondents, indicate that the expenditure on electricity is too small a part of their costs to invest in RES. As the size of the enterprise grew, managers more often complained about complicated procedures and legal regulations. The problem is also the lack of knowledge, as well as the lack of space to install renewable energy installations.

The respondents also indicated a group of activities, the implementation of which could result in increased interest in investing into renewable energy. These expectations include: 
a) easier access to financing - expected by $71 \%$ of respondents,

b) cheaper technology - indicated by $59 \%$ of respondents,

c) higher level of subsidies, attractive discounts - expected by $46 \%$ of respondents,

d) more accessible technology - indicated by $39 \%$ of respondents,

e) higher technology efficiency - expected by $20 \%$ of respondents,

f) less restrictive regulations - expected by $12 \%$ of respondents [27].

Many investments in energy efficiency are not made despite their apparent profitability. Internal obstacle rates are often set above the cost of capital to the firm. Reasons for these practices include limited rationality, prime-agent problems, and moral hazard. The policy implication is that government can simultaneously improve overall energy efficiency and increase private sector productivity by providing information and organizational services that go beyond the traditional regulatory framework [22].

\section{Materials and Methods}

In order to verify the research hypothesis, the survey in which the respondents were owners and managers of small and medium-sized enterprises based in the Greater Poland Voivodeship was carried out. In total, 640 questionnaires for small and medium-sized enterprises were submitted. The study was divided into 3 stages. The first stage included research aimed at, inter alia, identifying sources of financing investments of small and medium-sized enterprises in the designated area. At that time, the study covered 240 business entities. In order to confirm the above findings, another questionnaire survey was carried out (stage II). The scope of this survey covers 254 randomly selected enterprises from the Greater Poland Voivodeship. A computer system (spreadsheet) was used to collect the data. The third stage of the research was to identify the main problems of management in enterprises from the SME sector, and in particular to find out the opinions of entrepreneurs regarding investments in renewable energy sources. The study covered 147 business units (stage III).

Table 1. Analysis of the investment processes of the surveyed entities.

\begin{tabular}{|c|c|c|c|}
\hline Specification & Stage I & Stage II & Stage III \\
\hline $\begin{array}{c}\text { Business units covered by the } \\
\text { study, including: }\end{array}$ & $240 \mathrm{pcs}$. & $254 \mathrm{pcs}$. & $147 \mathrm{pcs}$. \\
\cline { 2 - 4 } & $100.00 \%$ & $100.00 \%$ & $100.00 \%$ \\
\hline Incurring investment expenses & $52.08 \%$ & $52.76 \%$ & $70.75 \%$ \\
\hline Introducing innovations & $28.75 \%$ & $27.95 \%$ & $25.17 \%$ \\
\hline Cooperating with R\&D units & $7.50 \%$ & $11.02 \%$ & $8.84 \%$ \\
\hline Family businesses & $35.00 \%$ & $31.10 \%$ & $45.58 \%$ \\
\hline $\begin{array}{c}\text { Expressing opinions on the } \\
\text { development of the RES market }\end{array}$ & - & - & $100.00 \%$ \\
\hline
\end{tabular}

Source: Compiled by the author based on surveys conducted in SMEs in the Greater Poland Voivodeship.

Information on the implementation of investment processes in companies indicated that $52 \%$ of entrepreneurs covered by the first and second stages of the research carry out investment projects. Among the entities participating in the third stage, $70 \%$ of the 
respondents indicated that they are implementing investments. Business owners pay much less attention to introducing innovative solutions in their businesses. It is a percentage of about $27 \%$ of the surveyed business entities in all three stages. Cooperation with research and development units is also not the most common choice made by entrepreneurs. On average, among the surveyed entities, approx. $9 \%$ of respondents showed that they cooperate with such entities.

When characterizing the surveyed group of companies in terms of organizational and legal form, it should be noted that the vast majority of the surveyed enterprises are microenterprises operating as natural persons doing business. It is a very popular form of running business because it is in many ways the simplest. In the first stage of the research, 151 entities conducting economic activity (63\% of all surveyed companies) participated. In the second stage there were 166 entities ( $65 \%$ of all surveyed family businesses). In the third stage there were 147 entities: 99 entities conducted economic activity, which was a bit over $73 \%$ of all entities surveyed). The remainder were companies (over $27 \%$ on average) as well as cooperative activities (almost $3 \%$ on average) and state-owned enterprises ( $4 \%$ on average).

Table 2. Organizational and legal form of the enterprises surveyed.

\begin{tabular}{|c|c|c|c|}
\hline Specification & Stage I & Stage II & Stage III \\
\hline $\begin{array}{c}\text { Business units covered by the } \\
\text { study, including: }\end{array}$ & $100.00 \%$ & $100.00 \%$ & $100.00 \%$ \\
\hline Economic activity & $62.92 \%$ & $65.35 \%$ & $73.47 \%$ \\
\hline Cooperative activities & $3.33 \%$ & $2.76 \%$ & $2.04 \%$ \\
\hline State enterprise & $3.75 \%$ & $4.72 \%$ & $0.00 \%$ \\
\hline Company & $30.00 \%$ & $27.17 \%$ & $24.49 \%$ \\
\hline Private Limited company. & $13.75 \%$ & $12.60 \%$ & $10.20 \%$ \\
\hline Civil law partnership & $8.33 \%$ & $5.12 \%$ & $7.48 \%$ \\
\hline Stock-offering company & $2.08 \%$ & $2.76 \%$ & $2.72 \%$ \\
\hline General partnership & $5.83 \%$ & $5.12 \%$ & $4.08 \%$ \\
\hline Limited liability partnership & $0.00 \%$ & $1.57 \%$ & $0.00 \%$ \\
\hline
\end{tabular}

Source: Compiled by the author based on surveys conducted in SMEs in the Greater Poland Voivodeship.

Most of the surveyed companies have been operating on the market for 10 to 20 years on average, more than $28 \%$ of the respondents. A similar percentage, almost $23 \%$, are entities that have been operating for 1 to 5 years. The smallest group were entities that had just started their activity and operated for less than one year.

Table 3. The period of the surveyed companies' operation on the market. 


\begin{tabular}{|c|c|c|c|}
\hline Specification & Stage I & Stage II & Stage III \\
\hline $\begin{array}{c}\text { Business units covered by the } \\
\text { study, including: }\end{array}$ & $100.00 \%$ & $100.00 \%$ & $100.00 \%$ \\
\hline Less than a year & $10.00 \%$ & $11.42 \%$ & $5.44 \%$ \\
\hline $1-5$ years & $22.50 \%$ & $22.44 \%$ & $23.81 \%$ \\
\hline 5-10 years & $20.00 \%$ & $20.47 \%$ & $21.09 \%$ \\
\hline $10-20$ years & $27.08 \%$ & $26.38 \%$ & $30.61 \%$ \\
\hline Over 20 years old & $20.42 \%$ & $19.29 \%$ & $19.05 \%$ \\
\hline
\end{tabular}

Source: Compiled by the author based on surveys conducted in SMEs in the Greater Poland Voivodeship.

Taking into account the range of operations of the surveyed enterprises, the vast majority of entities operate on the local market - on average $48 \%$, and only $22 \%$ on the regional market.

Table 4. The scope of activity of the surveyed enterprises.

\begin{tabular}{|c|c|c|c|}
\hline Specification & Stage I & Stage II & Stage III \\
\hline $\begin{array}{c}\text { Business units covered by the } \\
\text { study, including: }\end{array}$ & $100.00 \%$ & $100.00 \%$ & $100.00 \%$ \\
\hline Local & $56.25 \%$ & $47.64 \%$ & $36.73 \%$ \\
\hline Regional & $20.42 \%$ & $18.50 \%$ & $27.21 \%$ \\
\hline National & $9.17 \%$ & $22.83 \%$ & $24.49 \%$ \\
\hline International & $14.17 \%$ & $11.02 \%$ & $11.56 \%$ \\
\hline
\end{tabular}

Source: Compiled by the author based on surveys conducted in SMEs in the Greater Poland Voivodeship.

\section{Results}

\subsection{Investment activities in the field of renewable energy sources in the Greater Poland Voivodeship}

The questionnaire completed by the entities surveyed consisted of 6 areas. Entrepreneurs and managers answered questions about the company's current operations, sources of investment financing, and assessed their own attitudes in the context of undertaking innovative activities and cooperation with research and development units. Moreover, due to the ubiquity of applying ecological requirements, which lead to more and more changes in approaching the problem of rational use of natural resources, and thus to rational energy management, inquiries were made about investments in the field of renewable energy sources. In the next stages, the research on this topic will be continued, which will enable an analysis of 
investment projects related to environmental protection and an assessment of whether the society sees the future in RES as one of the ways to obtain "sustainable energy"?

In the course of the analysis of investment plans of the surveyed group of enterprises, it turned out that almost $65 \%$ of respondents would like to invest in a renewable energy source. However, among them, only $22 \%$ of entities are ready to take up such a challenge as soon as possible. On the other hand, $43 \%$ of entrepreneurs show their readiness to undertake this type of investment activities, but put them off until later.

Table 5. Answers to the question: If you had the opportunity, would you like to invest in a small renewable energy source?

\begin{tabular}{|c|c|}
\hline Specification & $\begin{array}{c}\text { Percentage of particular } \\
\text { responses }\end{array}$ \\
\hline Yes, as soon as possible & $21.77 \%$ \\
\hline Yes, but later & $42.86 \%$ \\
\hline I'd rather not & $6.12 \%$ \\
\hline Hard to say & $29.25 \%$ \\
\hline
\end{tabular}

Source: Compiled by the author based on surveys conducted in SMEs in the Greater Poland Voivodeship.

Among the units that have expressed their readiness to invest into renewable energy, more than $25 \%$ of units already have specific plans for the next year of operation. On the other hand, $12 \%$ of the enterprises analysed have plans for the next two years, and for almost $9 \%$ of enterprises, these plans are extended for over two years. Most of the respondents do not plan this type of investment in the long term, which may mean that they are ready to undertake investments in a very short period or do not plan such projects.

Table 6. Answers to the question: Does the company already have long-term action plans related to investing in renewable energy?

\begin{tabular}{|c|c|}
\hline Specification & Percentage of particular responses \\
\hline We have plans for the next year of operation & $25.17 \%$ \\
\hline We have an action plan for the next two years & $11.56 \%$ \\
\hline We have over two-year business plans & $8.84 \%$ \\
\hline We do not plan for the long term & $54.42 \%$ \\
\hline
\end{tabular}

Source: Compiled by the author based on surveys conducted in SMEs in the Greater Poland Voivodeship.

The analysis of factors inducing entrepreneurs to abandon investment plans in the field of renewable energy sources shows that almost $29 \%$ of the respondents indicated the lack or insufficient amount of financial resources. It should be noted here that investments in renewable energy sources are widely financed by banks and institutions that offer preferential loans for projects related to environmental protection, in particular for installations related to renewable energy. However, the mere presence of these programs is not enough. Entrepreneurs complain about too high financial costs and high initial payments. 
Table 7. Answers to the question: What are the reasons for the lack of investment plans in the field of renewable energy?

\begin{tabular}{|c|c|}
\hline Specification & Percentage of particular responses \\
\hline Lack of time needed for planning & $12.50 \%$ \\
\hline Lack of or insufficient funds & $28.75 \%$ \\
\hline Lack of qualified staff & $15.00 \%$ \\
\hline Lack of needed knowledge & $17.50 \%$ \\
\hline Planning is not necessary for a company of this size & $26.25 \%$ \\
\hline
\end{tabular}

Source: Compiled by the author based on surveys conducted in SMEs in the Greater Poland Voivodeship,

Further, the factor that influences the lack of investment plans in the field of renewable energy sources is the lack of the necessary knowledge and qualified staff. Companies experience the greatest difficulties at the beginning of their operations. They are related precisely to the lack of specialist knowledge, especially in the field of management under competitive conditions, with the emission of value without economic benefits or with the long-term process of building the image. A significant part of entrepreneurs knows that education in the field of environmental protection is an essential element in changing conditions, but not all of them follow the changes. The answer to the question about the need to plan is also interesting, as well as resources. As many as $26 \%$ of respondents do not see the need for planning. They belong mainly to micro and small groups.

Analysing the average waiting time for the reimbursement of costs incurred on account of investments in renewable energy sources, it can be seen that $21 \%$ of entities expect that the average payback period will be no longer than 2 years. On the other hand, among all entrepreneurs expressing their readiness to undertake this type of investment activities $23 \%$ admit that it is difficult for them to determine the estimated time of waiting for the return of incurred expenditure. The remaining percentage ranges in this group of responses are: $19 \%$ of respondents believe that a return period from 3 to 4 years is appropriate for this type of investment, $15.5 \%$ of respondents indicated a period from 5 to 6 years, $8 \%$ of respondents indicated a period from 9 to 10 years, and $7 \%$ of respondents of respondents indicated a period over 10 years.

Table 8. Answers to the question: Average waiting time for the reimbursement of costs incurred on investments in renewable energy sources.

\begin{tabular}{|c|c|}
\hline Specification & Percentage of particular responses \\
\hline Hard to say & $22.45 \%$ \\
\hline More than 10 years & $6.80 \%$ \\
\hline 9-10 years & $8.16 \%$ \\
\hline 7-8 years & $7.48 \%$ \\
\hline 5-6 years & $15.65 \%$ \\
\hline 3-4 years & $19.05 \%$ \\
\hline Less than 2 years & $20.41 \%$ \\
\hline
\end{tabular}

Source: Compiled by the author based on surveys conducted in SMEs in the Greater Poland Voivodeship. 
The most willingly chosen source of energy, which entrepreneurs would be ready to use, are solar collectors that provide savings on heat bills (over 29\%), and then photovoltaic panels that provide savings on electricity bills (over 28\%). The least popular source of renewable energy among entrepreneurs from the Greater Poland Voivodeship turned out to be biomass boilers or micro-biogas plants.

Table 9. Answers to the question: The list of renewable energy sources in which entrepreneurs would most willingly invest.

\begin{tabular}{|c|c|}
\hline Specification & Percentage of particular responses \\
\hline $\begin{array}{c}\text { Micro bio gasification - providing savings on } \\
\text { electricity bills }\end{array}$ & $6.48 \%$ \\
\hline $\begin{array}{l}\text { Small wind farms - providing savings on electricity } \\
\text { bills }\end{array}$ & $18.21 \%$ \\
\hline $\begin{array}{c}\text { Photovoltaic (PV) panels - providing savings on } \\
\text { electricity bills }\end{array}$ & $28.09 \%$ \\
\hline Biomass boilers - saving on heat bills & $3.40 \%$ \\
\hline Heat pumps - providing savings on heat bills & $11.42 \%$ \\
\hline Solar collectors - providing savings on heat bills & $29.01 \%$ \\
\hline None & $1.54 \%$ \\
\hline Hard to say & $1.85 \%$ \\
\hline
\end{tabular}

Source: Compiled by the author based on surveys conducted in SMEs in the Greater Poland Voivodeship.

After receiving the answers to the question 'What is the value of the project at your enterprise?' it turned out that over $54 \%$ of entities plan projects at the level of up to 100,000 PLN. Furthermore, 24\% of entities plan projects in the range from 100 thousand to 300 thousand.

Table 10. Answers to the question: What value of projects is planned in the enterprise in the field of renewable energy?

\begin{tabular}{|c|c|}
\hline Specification & Percentage of particular responses \\
\hline Up to 100,000 PLN & $54.55 \%$ \\
\hline $101-300$ thousand PLN & $23.64 \%$ \\
\hline $301-500$ thousand PLN & $9.09 \%$ \\
\hline Over 500,000 PLN & $7.27 \%$ \\
\hline Over PLN 1 million & $5.45 \%$ \\
\hline
\end{tabular}

Source: Compiled by the author based on surveys conducted in SMEs in the Greater Poland Voivodeship.

There is no doubt that the level of investment plans depends on the sources of their financing. Retained earnings were most often indicated as the main source of investment 
financing - almost 39\%, followed by the possibility of using subsidies from investment funds - over $17 \%$. Long-term loan appeared only in the third position. In the examined group of entities, there is a very large diversification of sources of financing investment projects, as evidenced by the coefficient of variation at the level of 1.092 .

Table 11. What is the potential source of financing investments in renewable energy?

\begin{tabular}{|c|c|}
\hline Specification & Percentage of particular responses \\
\hline Retained profit & $38.76 \%$ \\
\hline Owners' surcharges & $12.36 \%$ \\
\hline Capital of a new strategic investor & $1.12 \%$ \\
\hline Long-term loan & $16.29 \%$ \\
\hline Preferential loan & $2.81 \%$ \\
\hline Financial leasing & $6.18 \%$ \\
\hline Operating lease & $3.37 \%$ \\
\hline Subsidies from European Union funds & $17.42 \%$ \\
\hline Other (what?) & $1.69 \%$ \\
\hline
\end{tabular}

Source: Compiled by the author based on surveys conducted in SMEs in the Greater Poland Voivodeship.

\section{Conclusions}

The development of enterprises is also related to investments in energy. Investing is a longterm process in which the company spends cash in order to achieve specific economic effects in the future. As shown in the literature review, recent years have brought a significant increase in interest in energy investments, including renewable energy sources. The necessity to meet the requirements of the European Union in the field of energy conservation, and thus striving for the full concept of sustainable development, will be associated with an even more dynamic increase in the share of energy from renewable sources in total energy consumption.

Based on the literature available and conducted empirical research, the analysis of investment conditions in the field of renewable energy sources was made in the light of the requirements of sustainable development. The conducted survey studies concerned all issues related to the investment activity of SMEs in the Greater Poland Voivodship, with particular emphasis on investments in renewable energy sources.

The results of the research showed that the surveyed entities have different sources of financing and the level of incurred expenses, which depends on the nature of the investment activities made, knowledge in a given field and the ability to use the available training.

Summarizing the considerations on investment conditions in the field of renewable energy enterprises operating in the area of Greater Poland Voivodship, it can be stated that retained profit remains the main source of financing the investment activities of micro and small enterprises. Own funds were the source of financing of most investments, $16 \%$ of companies used a bank loan. However, there is still little interest in the EU support for companies among entrepreneurs from the Greater Poland voivodeship (17\%). There is a wide range of instruments supporting investments in the field of renewable energy sources, but not every entrepreneur is aware of it. As the reasons for not using the EU support, they indicate a low chance of obtaining a subsidy or complicated procedures when applying for a subsidy. 
The vast majority of investment expenditure in the analysed entities did not exceed the amount of PLN 100,000.

There was proved a research hypothesis about a moderate level of investment activities of companies from the sector of small and medium-sized enterprises in the Greater Poland voivodship. Despite the gradual increase in the number of investments in renewable energy sources, entrepreneurs still invest only to a limited extent. As a result of the analysis of investment plans of the surveyed group of enterprises, it turned out that almost $65 \%$ of respondents would like to invest in a renewable energy source. However, among them, only $22 \%$ of entities are ready to take on such a challenge as soon as possible and expect that the average payback period for the costs incurred due to the implementation of this investment will not exceed 2 years. On the other hand, $43 \%$ of entrepreneurs show their readiness to undertake this type of investment activities, but they postpone them and it is difficult for them to estimate the waiting time for the return of incurred expenditure.

\section{References}

1. Z. Hull, Świadomość Ekologiczna (Aura, Cracow, 1984)

2. A. Papuziński, SIEGE. 2, 12-27 (2014)

3. R. Sroufe, Prod. Oper. Manag. 12, 416-431 (2003)

4. The International Institute for Sustainable Development, Deloitte \& Touche, World Business Council for Sustainable Development, Business Strategy for Sustainable Development: Leadership and Accountability for the 90s (International Institute for Sustainable Development, Winnipeg, 1992)

5. Report of the World Commission on Environment and Developmnent. Available online: http://www.un-documents.net/wced-ocf.htm 9 (accessed on 1005 2021).

6. Z. Nowak, Problemy Ocen Środowiskowych, 2, 19 (1998)

7. M. Sokołowski, Aksjologia energetycznego prawa europejskiego, in Aksjologia prawa administracyjnego, 2 (Wolters-Kluwer, Warsaw, 2017)

8. M. Szyrski, Prawo energetyczne z uwzględnieniem odnawialnych źródel energii, in Instytucje materialnego prawa administracyjnego. Przegląd regulacji (UKSW, Warsaw, 2017)

9. Z. Karaczun, Wpływ rolnictwa na zmiany klimatyczne, jak można go ograniczyć? in Zmiany klimatu a rolnictwo (FDPA, Warsaw, 2008)

10. W. Golka, Energetyka a odnawialne źródta energii, in Popularyzacja prac badawczo rozwojowych z zakresu odnawialnych źródeł energii, SITR, Warsaw, Poland (2010)

11. W. Denisiuk, J. Piechocki, Technologiczne i ekologiczne aspekty wykorzystania (UWM, Olsztyn, 2005)

12. R. Mędrzycki, Odnawialne źródla energii w aspekcie zrównoważonego rozwojuzarys problematyki, in Tworzenie iwykorzystanie energii ze źródeł odnawialnych. Problemy administracyjno-prawne (UKSW, Warsaw, 2016)

13. Judgment of the Court (Third Chamber) of 22 February 2018, OJ in EU, Case C336/16 (2018)

14. European Parliament, Directive 2006/32/EC of the European Parliament and of the Council of 5 April 2006 on energy end-use efficiency and energy services and repealing Council Directive 93/76/EEC (2006)

15. K. Piwowarczyk-Ściebura, T. Olkuski, Energy Policy Journal, 19, 93-108 (2016)

16. B. Fraś, O. Ivashchuk, Energy Policy Journal, 2, 25-40 (2017) 
17. European Commission. European Energy and Transport Trends to 2030 (Brussels, 2010)

18. K. Prandecki, Ksztaltowanie polityki ochrony środowiska i polityki energetycznejrefleksje w perspektywie 2020, in Innowacyjna Polska w Europie 2020. Szanse i zagrożenia trwałego rozwoju (PWE, Warsaw, 2010)

19. S. J. DeCanio,EN. POL. 21, 906-914 (1993)

20. Motywacje i bariery dla poprawy efektywności energetycznej MŚP. Available online: www.kig.pl/naszglos/badania (2021)

21. Dziaduszyński, K; Tarka, M; Trupkiewicz, M; Szydłowski, K. Rozwój odnawialnych źródeł energii w sektorze Mikro, Małych i Średnich Przedsiębiorstw, w tym możliwość zastosowania rozwiązań prosumenckich. Stan obecny i perspektywy rozwoju (2018) Available online: https://www.teraz-srodowisko.pl/media/pdf/aktualnosci/6284analiza-rozwoj-OZE-w-sektorze-MSP.pdf. (2021).

22. Inwestycje energooszczędne małych i średnich przedsiębiorstw. Available online: http://nfosigw.gov.pl/oferta-finansowania/srodki-krajowe/programypriorytetowe/inwestycje-energooszczedne-w-msp/ (2021)

23. Ministry of Infrastructure and Development. Umowa Partnerstwa (2013)

24. National Fund for Environmental Protection and Water Management. Przewodnik po programach priorytetowych NFOŚiGW na lata 2015-2020 (2015)

25. Program Finansowania Zrównoważonej Energii w Polsce. Available online: http://www.polseff.org/ (2021)

26. K. Pasławski, 87 proc. firm rezygnuje z OZE przez koszty inwestycji, CRN (2020)

27. T. Długosz, Instrumenty wspierania energetyki ,,niekonwencjonalnej", in Publiczne Prawo Gospodarcze. System Prawa Administracyjnego (Warsaw, 2018) 